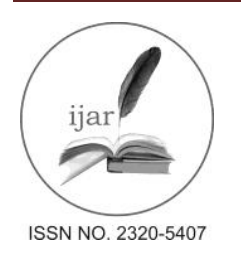

Journal homepage: http://www.journalijar.com

Journal DOI: 10.21474/IJAR01

INTERNATIONAL JOURNAL

OF ADVANCED RESEARCH

RESEARCH ARTICLE

\title{
SOME PROCEDURAL ISSUES CONCERNING THE IMMEDIATE APPEAL TO THE EXECUTION OF JUDGMENTS.
}

\author{
Esanova Zamira Normurotovna
}

\section{Manuscript Info \\ Manuscript History: \\ Received: 18 February 2016 \\ Final Accepted: 19 March 2016 \\ Published Online: April 2016}

Key words:

Court decisions, execution of court decisions, immediate executions of court decisions, contents of decisions, the provisions of court decisions.

*Corresponding Author

Esanova Zamira

Normurotovna

\begin{abstract}
In this article described the issues that are connected with the immediate execution of court decisions. The order of court decisions are set in the article 14 of the Civil Procedure Code of the Republic of Uzbekistan. As well as it is listed the decisions that are subjected to immediate execution. Besides, analyzed the right of court for the immediate execution. In conclusion it is established the priorities of immediate executions of court decisions.
\end{abstract}

Copy Right, IJAR, 2016,. All rights reserved.

\section{Introduction:-}

Chapter 18 of the Civil Procedure Code of the Republic of Uzbekistan (Articles 203-223) is devoted to the court decision, the decision of the court of first instance, which hears the case on the merits. Judicial decisions in its content and form are divided into general, optional and default judgment, according to the method and date of execution - simple (on a common basis) solutions and decisions, which are immediately enforceable.

According to article 203 of the Civil Procedure Code of the Republic of Uzbekistan at the end of the first instance the court makes a decision.

The judge reviewed the case, the final part of the court hearing is given the right to make and announce a decision.

The Court shall decide on behalf of the Republic of Uzbekistan. This requirement is the most responsible and serious demands before the justice. Among the procedural documents in respect of the judgment and decisions used the phrase "on behalf of the Republic of Uzbekistan". This requirement establishes the State protection of the rights and interests of citizens, as in accordance with article 93 of the Constitution the President introduces to the Senate of the Oliy Majlis candidates for the posts of Chairs and judges of the Supreme Court, the Chair and judges of the Supreme Economic Court, and appoints and dismisses judges of regional, inter-district, district, municipal, military and economic courts.

Making the decision on behalf of the Republic of Uzbekistan may be characterized by the fact that the decision must be of peculiar final, binding and reliability, as well as under article 18 of the CPC of Uzbekistan judgments, decisions, court orders must be lawful, reasonable and fair.

The court's decision shall be made immediately after the proceedings. This requirement pursues its goal the protection of procedural interests of the judge who issued a procedural decision and stakeholders, compliance with the procedural order, the prevention of missing the term appeal or protest against the court decision on the part of those involved in the case. Usually the phrase "immediately" provide training at the same time on the same day, 
immediately after the announcement of the decision of discussion in the conference room without a break and without delay the imposition of announcement of the decision on the next day. In exceptional cases of particularly complex cases drawing a reasoned decision can be delayed for a period of not more than three days, but the operative part of the decision, the court must declare in the same meeting in which the hearing was over. At the same time the court declares that a person involved in the case, can get acquainted with a reasoned decision. Announced the operative part of the decision signed by the judge (judges) and attached to the case.

Article 204 of CPC of Uzbekistan stipulates that the decision is decided by the judge in a separate room (the deliberation room) is set forth in writing and signed by the judge. During resolution solutions presence of other persons (except judges anyone, even the clerk of the court) is not allowed. In addition, the judge when deciding in chambers is prohibited to discuss the matter with others by telephone and other means of communication.

As stated above, the decision on the method and deadlines are executed on a general basis and immediately.

Article 219 of CPC of Uzbekistan indicated decisions to be executed immediately, which include the court's decision:

- the award of alimony;

- the award of employee wages, but no more than three months;

- the award of payments in compensation for damage caused by injury or other impairment of health, as well as the death of a breadwinner;

- to reinstate an employee with whom an employment contract has been terminated illegally or an employee illegally transferred to another job, and to amend the grounds for termination of the employment contract;

- to hospitalize a person sick contagious form of tuberculosis, a specialized branch of TB facilities involuntary or prolongation of hospitalization;

- for claims recognized by the respondent in a proceeding in court - in whole or in part, the corresponding recognition.

The law in determining the decisions to be executed immediately take into account the rights and interests of citizens, their family and financial condition, the property of the utility of civil society and the state of affairs, social and political importance of civil cases. On the immediate execution specified in the operative part of the decision.

For example, the court examined the case 1-3705 / 11 on the suit from Salimova Robiya Sobirovna, the defendant Abdullah Salimov Alievich ${ }^{1}$, upheld the claim for alimony. The court ordered the defendant Salimov Abdullah Aliev to pay alimony in favor of the plaintiff Salimova Robiya Sobirovny for content that Salimov Javlon Abdullaevich born 06.10.1997 years Olim Salimov Abdullah, born 10.07.2011 year, in the amount of 1/3 of the monthly salary and other income, from 13 April 2011, established the payment of the defendant Abdulla Salimov Aliyevich state fee in the amount of 6210 (six thousand two hundred and ten) sum. The immediate execution of the decision is urgent, and it is the right of parties, who do not agree with the decision, to appeal to the appellate complaint or protest by the court in Tashkent city civil court within 20 days ${ }^{2}$.

The operative part of the decision indicates the immediate execution of the decision.

It is the right of the court to allow the immediate execution of the decision as stated in article 220 of the Civil Procedural Code of Uzbekistan, according to which the court may allow the immediate execution of all or part of the decision in cases where the plaintiff and the defendant agreed with the decision and its immediate execution; the award of remuneration due to the author for using the results of its intellectual property; in all other cases where, because of the particular circumstances of a slowdown in the execution of the decision may result in significant damage to the creditor or when the execution itself is not possible.

The grounds for immediate execution of decisions on such circumstances in terms of protection of the rights and interests of the plaintiff and the defendant are statements and consent of the parties.

In cases of immediate execution, on the grounds specified in the law, the parties' agreement entered into the record of the hearing and signed by the parties. If the consent of the parties, expressed in written statements, addressed to the court, these statements are attached to the case, as stated in the minutes of the hearing.

\footnotetext{
${ }^{1}$ The names were intentionally changed.

${ }^{2}$ Taken from Tashkent city, Mirzo Ulugbek regional court, civil case dated June 7, 2011.
} 
Assuming immediate execution on the grounds specified in the law, the court may require the plaintiff to ensure the rotation of execution in case of cancellation of the decision of the court.

After the decision, within the period of appeal and protest, the question of approval of immediate execution of the decision is considered in court session with notification of persons participating in the case, however, the nonappearance of these persons is not an obstacle to the resolution of the question of immediate execution.

On the court ruling on immediate execution of the decision may be filed a private complaint or private protest could be brought. Filing a private complaint or private protest bringing does not to suspend the execution of this ruling. Article 221 of the CPC of Uzbekistan provides for the inadmissibility of the immediate execution of the decision. Denial works when immediate execution leads to a change of the subject of the claim, and it aims protecting the rights and interests of citizens.

In particular, the immediate execution of the decision is not allowed:

1) when the immediate execution can cause such changes in the property, in case of cancellation of the decision, it will be impossible or very difficult to bring it to its previous state; 2 ) in cases of eviction from the premises.

The content of article 221 of CPC of Uzbekistan aimed at ensuring the enforcement of the decision, which is not subject to immediate execution (decision enforceable on general grounds). Provision of such decisions is carried out according to the grounds and procedure for the measures set out in chapter 24 of the CPC of Uzbekistan (articles 248-258). Under the provision of the claim referred to application of legal action against the defendant in the course of preparing the case for trial or trial by a court, or persons involved in the case on the facts of the case to ensure the execution of the decision. Ensuring action is allowed not only in the proceedings in the court, but in the course of execution and it provides for enforcement actions. Secured claim seeking enforcement (avoiding the destruction of the object of the claim, complexity of execution, saving the possibility of execution, etc.) the decision.

Where appropriate, the enforcement is allowed on the initiative of a bailiff or a statement of the claimant. In this case, in accordance with article 21 of the Law "On execution of judicial acts and acts of other bodies", bailiffs to ensure their interaction with government agencies, credit and other organizations sent to the relevant government authorities (inventory, road safety, banks) requests for information on identifying the presence of real estate on behalf of the defendant.

The bailiff, according to the law and in order to ensure the interests of the creditor and the execution of a court decision, adopts a resolution on the adoption of measures to secure a claim against the debtor' estate and imposes a duty on the seizure of property of the debtor, and sends the relevant authorities a copy.

For example, in the court asked the plaintiff Rashidov I. addressed to the defendant Rashidova E. with a claim for division of property. The Court, having examined the materials of the case, in order to avoid complications and impossibility of execution of the judgment, found it necessary to seize the disputed premises in accordance with article 248 of CPC of Uzbekistan. In order to ensure the claim, it was prohibited to perform any notarial acts in relation to the houses located at the city of Tashkent, Mirabad district, street Oydin Building 25, Apartment 12, Mirabad district, street Kushbegi Building 12, Apartment 164, Mirabad district, street Temur Malik Building 32 , Apartment 18, as well as cottages, located at Tashkent region, Kibrai district, street "Dogwood OLMA", belonging to the plaintiff Rashidov I. and E. Rashidova. And the execution of the seizure of the above premises was entrusted to the public notary №1 located in Kibray district was established the rest of the deferred payment of the state fee for the permission of the civil case on the merits, the possibility of the parties do not agree with this definition, challenged or appealed this determination within 10 days of the Tashkent city court for civil cases ${ }^{3}$.

Studies have shown that in the process of execution of court decisions, which are subject to immediate execution there are some difficulties: the change of residence of the defendant or the defendant non-residency to the specified address; the uncertainty of what the debtor from any (legal entity) or its affiliated companies (branch) is necessary to recover the debt and therefore requesting the court which issued the writ, an explanation about this misunderstanding. In addition, the civil procedure law and practice can meet other conditions that cause difficulty in the immediate execution of judicial decisions.

\footnotetext{
${ }^{3}$ From the definition of the Mirabad Inter-District Court in Tashkent on civil cases, March 14, 2011.
} 
With regard to the immediate implementation of the decisions, the judge makes the determination.

According to paragraph 4 of the Resolution of the Plenum of the Supreme Court of the Republic of Uzbekistan immediate execution of decisions (article 220 of CPC of Uzbekistan) is one of the definitions necessarily submitted as a separate document ${ }^{4}$.

As stated in article 222 of the CPC of Uzbekistan, the Court may enforce the decision, not subject to immediate execution, the rules established to ensure the claim, if no measures are taken to secure the claim, execution of court decisions may become complicate or their execution may be impossible.

In conclusion, it can be noted that the immediate enforcement of court decisions:

$>\quad$ Increases efficiency in the enforcement of judicial decisions;

$>\quad$ Take into account the family and the material possibilities of the parties (especially the creditor);

$>\quad$ Prevention of negative moments in the form of deferment, performance or termination of deposits and prevents circumstances that do not allow the execution;

Enhances the protection of the rights and interests of citizens, prevents repeated violation of the procedural rights and duties of the court;

$>\quad$ Leads to a positive end of the administration of justice.

\footnotetext{
${ }^{4}$ Resolution of the Plenum of the Supreme Court of the Republic of Uzbekistan № 7 "On the determination of the courts of first instance in civil cases" from May 25, 2012.
} 